\title{
Teachers' Perceptions and Implementation of Professional Development in Writing Instruction
}

\author{
Beth C. Brabham \\ Dept. of Teaching Learning and Culture Texas A\&M University \\ MS 4232 College Station, TX, 77843 USA \\ Tel: 1-979-845-8384 E-mail: beth.brabham@midwayisd.org \\ Janet A. Nichols \\ School of Learning and Teaching, The University of Maine \\ MS 5749 Merrill Hall Orono, ME, 04469 USA \\ Tel: 1-207 581-3117 E-mail: janet.nichols@maine.edu \\ William H. Rupley (corresponding author) \\ Dept. of Teaching Learning and Culture Texas A\&M University \\ MS 4232 College Station, TX, 77843 USA
}

Tel: 1-979-845-8384 E-mail:w-rupley@tamu.edu

William Dee Nichols

School of Learning and Teaching, The University of Maine

MS 5749 Merrill Hall Orono, ME, 04469 USA

Tel: 1-207 581-3117_E-mail: william.nichols1@maine.edu

Timothy V. Rasinski

Kent State University

White Hall 401 Kent, OH 44242

Tel: 330-672-2580 E-mail: trasinski@kent.edu

David Paige

Annsley Frazier Thornton School of Education

Bellarmine University 2001 Newburg Road Louisville, KY 40205

Tel: 502-272-8153 E-mail: dpaige@bellarmine.edu 
Received: May 22, 2016 Accepted: June 30, 2016 Published: August 1, 2016

doi:10.5296/jse.v6i3.9620 URL: http://dx.doi.org/10.5296/jse.v6i3.9620

\begin{abstract}
This mixed-methods study investigated teachers' perceptions and implementation of professional development in writing instruction at a United States public high school campus. A layered approach to professional development was utilized: (1) one group received weekly professional development during a Professional Learning Community (PLC) and participated on a district writing team, (2) one group received weekly professional development during a PLC and received instructional coaching, and (3) one group received only weekly professional development during a PLC. Data were gathered on teachers' responses to their perceptions of professional development received, teachers' body and verbal language during PLCs and professional development, reflection notes documented by teachers receiving instructional coaching, and interviews of the teachers who received instructional coaching. Analyses of the data demonstrated application of the newly learned instructional practices in the classroom indicating the value teachers placed on learning during PLCs. While no significant differences were noted from the analysis of the pre-to post-observations for teachers in any group it was evidenced that the teachers who received instructional coaching became more aware of their instructional practices and had a greater sense of collaboration and collegiality as a result of the coaching process.
\end{abstract}

Keywords: professional development, writing instruction, professional learning communities, teacher collaboration, instructional effectiveness, student writing achievement 


\section{Introduction}

Public schools in the United States are spending as much as \$20 billion USD a year on professional development (PD) yet the professional development offered has not produced the desired results (Guskey, 2009). The PD offered from school districts tend to be delivered in a one-time manner from local sources and is often delivered by individuals with limited content expertise. PD should be content focused, contain active learning, be well organized, have sufficient duration, and include the collective participation of teachers as well as follow up after the initial PD (Desimone, 2009). However, school organizations and teachers have complex jobs and time demands, which make it difficult to offer sustained PD that produces changes in teacher beliefs and instructional practices as well as increased student learning outcomes.

Darling-Hammond and her colleagues (2009a) researched the types of PD that teachers in the United States typically receive. Their study pulled data from the 1999-2000 and 2003-2004 staff surveys from the National Center for Education Statistics. Over this period of time, the highest form of PD for teachers (92\%) was conducted in traditional settings such as workshops and conferences. During the 2003-2004 school year, 83\% of teachers stated that their PD was related to their content area, but felt that the training was not very thorough. Teachers also reported that only $59 \%$ of the training they received pertained to their specific content areas was helpful (Darling-Hammond, et al., 2009a).

A follow-up study was conducted by the National Staff Development Council in 2008 to determine if growth had occurred since the original study. Results indicated that the United States had actually declined in delivering teachers the strong, sustained PD proven to make a difference in student achievement (Chung Wei et al., 2010).

When PD is delivered in what United States educators know to be a traditional format, it usually consists of trainings over a short time period (Chung Wei, et al., 2010). The time duration of PD in the US does not reach a level of intensity that connects teachers to effective training necessary for knowledge acquisition to implement change in how they teach and how students' learning improves (OECD, 2014).

Although time duration of PD is noted as insufficient, educators recognize the need for connecting professional learning to students' classroom learning outcomes (Applebee \& Langer, 2009; Archibald, Coggshall, Croft, \& Goe, 2011). Educators acknowledge the connection between what teachers learn and increased student performance. Teachers have to acquire new knowledge to improve how they teach and PD is the best way to inform teachers of best practices. However, the most effective way to provide strong PD for effective teaching is still elusive (Young, 2013). For implementation of what teachers learned during PD, best practices in delivering PD must occur. Professional development cannot just be a one-day workshop with no follow up. Many high-achieving nations provide five times the quantity of PD and collaboration compared with the US, where the typical PD does not extend beyond a single training, and teachers do not believe they are capable of implementing such a sparse bit of knowledge. 
In order for teacher learning to be applicable in the classroom, professional development needs to be designed in ways that foster acquisition and application of new teacher learning (Loucks-Horsley, S., Stiles, K.E., Mundry, S., Love, N., \& Hewson, P.W., 2010). According to Loucks-Horsley, et al. (2010) the best way to ensure that professional development translates teacher learning into classroom application is when the professional development is driven by a well-defined vision of effective classroom learning and teaching, is designed to address student learning goals and needs, provides opportunities for teachers to build their content and pedagogical content knowledge that allows teachers to reflect on current practices and is continuously evaluated and improved. The researchers go on to suggest that professional development should be research based and must engage teachers as adult learners in the pedagogical approaches they will use with their students and must provide teachers with opportunities to collaborate with colleagues and other experts to improve their practice. When teachers are supported in developing their professional expertise and provided with opportunities to share this new knowledge in leadership roles and can link with other professional aspects of the educational system then professional development is deemed effective.

In spite of these recommendations, professional development continues to not connect to the specific needs of the teachers or students (Chung Wei, Darling-Hammond \& Adamson, 2010). If teachers are to have the tools they need to ensure that students achieve academically, and "research shows that teacher quality is the single most power influence on student achievement," (Chung et al., 2010, p. 8) then critical analyses should be focused on how PD is conducted and offered.

\section{Related Literature}

\subsection{Professional Development for English Teachers Who Teach Writing}

Teachers' knowledge about the complex process of developing writing through reading and critical thinking needs to be further examined as the United States wrestles with the revelation that the nation's students are failing as proficient writers. Graham and Perin (2007) report that over $70 \%$ of students across the United States in grades 4-12 are not proficient as writers and nearly half of students who graduate high school and attend college are not ready for college writing.

Students' poor writing performance links to a lack of effective PD that equips teachers with knowledge, instructional methods and support to enhance the quality of their writing instruction. Writing teachers often teach based on factors such as their personal confidence, experience, and knowledge of writing (Fleischer, 2004; Limbrick, Buchanan, Goodwin, \& Schwarcz, 2010).Many teachers report that they feel ill-prepared to teach writing. Half of all secondary teachers surveyed reported that they had no knowledge or skills for teaching writing. Yet, when the professional development offered is focused on strategies for teaching writing, student achievement in writing increases (Fearn \& Farnan, 2007; Flint, Zisook, \& Fisher, 2011). 
The above issues point to the need for professional development that address teachers' confidence as writing teachers and their knowledge about writing. Such an approach would allow teachers to reflect on the effectiveness of their own teaching practices and why they teach writing the way they do (Applebee \&Langer, 2009). Teachers who participate in professional development that examine their own teaching practices for writing through reflective inquiry-based approaches increase their confidence and ability as writing teachers (Limbrick et al., 2010). This indicates a reciprocal relationship between confidence and implementation of effective instructional strategies for writing.2.2Importance of Critical Thinking and Writing

Writing is a process that occurs through thinking (Reither, 1985). Teaching students to employ critical thinking in their writing is a necessary and key element of the United States Common Core State Standards (CCSS). Mehta and Al-Mahrooqi (2015) identified ways in which teachers can equip students to develop critical thinking skills. These involve helping students discover their prior knowledge and biases about a subject, teaching them how to address their biases through identifying sources that either support or refute the biases, and teaching them to address their beliefs with arguments that are based on readings and other sources. Without the critical thinking prior to writing, a person is likely writing without a larger purpose in mind and possibly with bias and undeveloped thoughts (Mehta \& Al-Mahrooqi, 2015). Once critical thinking has been integrated into the writing process, the writing of a person then becomes a way to communicate with others. Writing has been clearly defined as a language process that is focused on communication (Heilman, Blair, \& Rupley, 2002). Essentially, the writer communicates information to a reader and the reader comprehends or reconstructs a credible understanding of the author's message (Rupley, Nichols, \& Blair, 2008).

One way to address writing proficiency and enhance teachers' understanding of the connection between critical thinking and the communicative properties of reading and writing can be through the creation of Professional Learning Communities (PLCs). Although most schools adopt a mission or vision that refers to creating a supporting and encouraging classroom environment for learning, they often do not include the idea that teachers are a part of that learning (DuFour, 2004). Teachers ought to assume the responsibility of learner outcomes as well as realize that today's students are tremendously different from when they were students. Teachers of writing can embrace the notion that "the core mission of formal education is not simply to ensure that students are taught but to ensure that they learn" (Dufour, 2004, p. 7).

The link between teachers learning and teaching critical thinking skills can be done within PLCs. There exists a fair amount of knowledge on the effective use of PLCs where teachers use their own critical thinking skills to examine their classroom practices to determine whether or not they are pushing students to think at higher levels than what normally happens in classrooms (Phillips, Nichols, Rupley, Paige, \& Rasinsk, 2016). Most portrayals of PLCs include common components such as teachers sharing a common purpose for how students learn, teachers working collaboratively towards that purpose, and teachers all agreeing that they work as a team in order to see students learn (Blankstein, 2004). This focused purpose and approach is more meaningful and effective than traditional approaches to professional development (Schmoker, 2006). Effective PLCs support learning new knowledge, and the 
training is ongoing and long-term. Many factors are central in creating the time for all teachers to come together as a learning community. In order for PLCs to function as they should, leaders need to create an environment that promotes collegiality and collaborative learning (Jaquith, 2013). As PLCs promote professional growth and can occur as teachers understand that this interactive environment fosters collaborative learning.

\subsection{Instructional Coaching Writing Instruction}

Coaching is seen as a powerful and highly effective way in helping teachers implement new learning into their classrooms and sustain P D. Lotter, Yow, and Peters (2014) found that when both coaches and teachers work together in ways that promote inquiry through critical reflection of one's practices, teachers are more likely to make connections between their instruction and the inquiry process they are experiencing and will make that a part of their own instructional routine. Likewise, Teemant (2013) found that coaching does impact teacher attitudes and resulted in increased students' performance.

When employing instructional coaches in a school, campus leaders must choose people who are equipped to skillfully coach others. Loucks-Horsley et al. (2010), identify five key elements of coaching:

- Teachers focus on learning or improvement;

- A climate of trust, collegiality, and continuous growth is cultivated;

- Coaches are well prepared with in-depth content knowledge and adult learning skills;

- Mechanisms for observing practice and providing feedback are critical; and

- Opportunities for interaction are provided (p. 226).

Individuals, who have relationship skills, foster trust, expertise in content, and communication skills, can be effective coaches for teachers. Anderson, Feldman, and Minstrell (2014) found a relationship between stronger teaching practices and the time spent between teachers and their coaches. As coaches begin to work with teachers, transfer of learning occurs. Teachers will use their new learning more frequently, will retain their new skills longer, and they will have a greater understanding of why their practices needed to change (Joyce \& Showers, 2002).

Instructional coaching can focus on many different aspects of education, but Knight (2009b) narrows it to a framework that creates a focus on four key areas: classroom management, content planning, instruction, and assessment for learning. As instructional coaches develop a trusting relationship with teachers and use a framework such as this, they can identify critical areas that need attention. With an ongoing collegial relationship, and a focus for planning what needs to be addressed, teaching practices improve and students are in an environment designed for learning.

\subsection{Sustained Professional Development}

Ongoing and sustained professional development enables teachers to acquire knowledge that directly connects to teaching practices in ways that improve their students' writing achievement. Allowing for the time it takes to help teachers learn and positively change their teaching practices is important. Yoon, Duncan, Lee, Scarloss, and Shapley (2007) evaluated 
more than 1,300 studies that addressed teacher staff development, and only 9 met the What Works Clearinghouse Evidence Standards and demonstrated a direct correlation between intense and ongoing professional development and student achievement. From these nine studies, the average amount of time teachers participated in professional development was 49 hours over a 6 to 12 month time period. When teachers receive training that is meaningful, effective and targeted, and occurs for more than a one-day session, teaching practices can change.

Other reports support the fact that professional development should be long term. Teachers need nearly 50 hours of sustained professional development in order to see student achievement gains (Darling-Hammond et al., 2009a; Yoon et al., 2007). In 2003-2004, the Schools and Staffing Survey reported that more than $50 \%$ of teachers received less than 16 hours of professional development during a one-year period (Darling-Hammond, et al., 2009a)

Long-term and sustained professional development allows for teachers to examine, evaluate and change their current practices in order to improve instruction. When teachers follow research-driven approaches to professional development that involves ongoing training, they are able to reflect on why they do what they do and believe what they believe as educators (Limbrick, Buchanan, Goodwin, \& Schwarcz, 2010). Ongoing sustained PD enables teachers the opportunity to reflect and challenge one's practices and occurs over time as teachers learn more about their content, pedagogy, best practices, and how all of it relates to their present methods of instruction.

The establishment of PLCs that utilize instructional coaching (DuFour, 2004; DuFour \& Eaker 1998 ) is a critical component of sustained professional development. PLCs that include instructional coaches help promote change and can lead to effective professional development. Prytula's (2012) study of teachers' metacognition within a PLC environment determined that teachers were more able to recognize what they were thinking in their own teaching practices and why adjustments should to be made. When teachers have time to reflect on their teaching with an instructional coach in a supportive community, they are better able to learn from one another and discern what changes they need to make as individuals. Prytula's study also revealed that the instructional leaders of PLCs were also metacognitive as they learned and led other teachers. Teacher leaders promote positive change when they understand and employ best practices and can lead their teams in that direction.

Change for many teachers can be very difficult. However, Darling-Hammond (1995) indicated that change in schools occur when teachers have an environment that allows them to work together in ways that promote student achievement. In order for teachers to utilize PLCs that produce the desired results for students, teachers need to work together and support one another to implement needed instructional changes. Teachers are in a profession where change is common and does not last long; therefore, teachers do not always want to accept that change is needed (Marzano, Waters, \& McNulty, 2005, p. 65). Lewis (2011) noted that "communication plays a critical role in fostering the fad of change in organizations" (p. 22). The reason for needed instructional changes must be communicated clearly and well to teachers in order for them to buy into change and to understand consequences of not changing. 
The present study examined how a US public school, Wildflower (pseudonym) Independent School District (WISD) engaged in professional development that focused on the best practices for writing instruction. Research indicates that most teachers use a variety of methods with which to teach writing, but also indicates that teachers devote less than 90 minutes a week to writing in the classrooms (Troia, Lin, Cohen, \& Monroe, 2011).WISD high school English teachers historically devoted a limited amount of time to writing instruction and used a variety of approaches to teach. Thus, a goal of WISD was to address professional development for teachers of writing so that all teachers become equipped with proper knowledge and best practices for teaching writing with the anticipation that students will not only meet expectations on state writing assessments, but they will also be ready for life beyond high school.

\section{Methods}

\subsection{Setting}

The $81^{\text {st }}$ Texas Legislature decided in 2009 through House Bill 3 that the STAAR test would replace the TAKS test in order to create a more rigorous assessment that was aligned to state standards, ensure that the state was measuring students' postsecondary readiness, and help determine as early as possible whether or not students were "on track" to be successful as they moved from grade to grade (TEA, 2014c, p. 78). WISD began working to address areas that were identified as weak in performance, including writing. The school district administrators supported the plan to work with English teachers at the high school level to increase student performance through the implementation of PLCs, instructional coaching, and establishment of a vertical writing team that included English teachers from grades 6-12.This study involved a mixed-method approach of collecting data in order to analyze the effects of professional development provided to English teachers at the high school in WISD(Creswell, 2014; Creswell, Plano, Gutmann, \& Hanson, 2003). The first level of support for these teachers involved a weekly PLC each Friday for 45 minutes dedicated to the professional development topics of improving writing instruction and the environment of the writing classroom. The professional development time was led by either the researcher, a member of the secondary writing team, or by an outside consultant who was an expert in writing. An additional layer of professional development was added by involving 4 of the 18 English teachers from the high school on a vertical writing team that also included teacher representatives from grades 6,7 and 8. This team spent an average of six hours each month, face-to-face, working on district writing goals.

A final layer of support was designed for 3 of the 18 English teachers at the high school who voluntarily participated in an instructional coaching program. This program was to further strengthen the implementation of the professional development learned through PLCs and to focus on specific goals each teacher had for his or her classroom. The goals for these three teachers focused on student engagement during writing instruction, incorporating writing instruction that was effective and research-based, and providing structure for student writers of all abilities. These 3 teachers worked for a total of 10 weeks and approximately 2-4 hours each week with either the researcher who served as their instructional coach or on their own time. 


\section{Macrothink}

The study was conducted at WISD high school, which is the only high school in the district. This particular campus first opened in the fall of 2003, and served 2,218 students at the time of the research study. On the Texas Academic Performance Report published by TEA (2014d), the percentage of economically disadvantaged students on the campus was $24.4 \%$, and the percentage of students identified as at-risk was $27.6 \%$. The ethnic breakdown of students was 13.7\% African American, 19.8\% Hispanic, 58.4\% White, 1\% American Indian, 5\% Asian, and $2.1 \%$ two or more races. All 18 English teachers at the high school voluntarily participated in this study as a part of their standard expectations for professional development from the campus and district administrators. All teachers knew that expectations were to improve their quality of writing instruction in order to improve students' writing achievement. Furthermore, they knew that data would be collected and used to identify strategies to enhance the quality of writing instruction. The three teachers who participated in the instructional coaching program as a part of this study also did so voluntarily. The researchers prior to this study selected the four teachers who participated on the district writing team. Of the teachers involved in this study, five taught ninth grade English, four taught tenth grade English, three taught eleventh grade English, four taught twelfth grade English, and two served as academic intervention English teachers. Table 1 below explains the breakdown of education, gender and years of experience for all teachers involved in this study. The researcher, the writing team members, and an outside writing expert conducted the professional development through PLCs. The researcher conducted the coaching. 
Table 1.Teacher demographics

\begin{tabular}{|c|c|c|c|}
\hline Teaching Position & Gender & Education Level & Years Teaching \\
\hline $9^{\text {th }}$ Grade Teacher 1 & Female & Bachelor's Degree & 14 \\
\hline $9^{\text {th }}$ Grade Teacher 2 & Female & Bachelor's Degree & 2 \\
\hline $9^{\text {th }}$ Grade Teacher 3 & Female & Bachelor's Degree & 4 \\
\hline $9^{\text {th }}$ Grade Teacher 4 & Female & Bachelor's Degree & 18 \\
\hline $9^{\text {th }}$ Grade Teacher 5 & Female & Bachelor's Degree & 29 \\
\hline $10^{\text {th }}$ Grade Teacher 1 & Female & Bachelor's Degree & 6 \\
\hline $10^{\text {th }}$ Grade Teacher 2 & Female & Bachelor's Degree & 10 \\
\hline $10^{\text {th }}$ Grade Teacher 3 & Female & Bachelor's Degree & 17 \\
\hline $10^{\text {th }}$ Grade Teacher 4 & Male & Bachelor's Degree & 1 \\
\hline $11^{\text {th }}$ Grade Teacher 1 & Female & Bachelor's Degree & 37 \\
\hline $11^{\text {th }}$ Grade Teacher 2 & Male & Master's Degree & 5 \\
\hline $11^{\text {th }}$ Grade Teacher 3 & Female & Bachelor's Degree & 16 \\
\hline $12^{\text {th }}$ Grade Teacher 1 & Female & Master's Degree & 26 \\
\hline $12^{\text {th }}$ Grade Teacher 2 & Male & Bachelor's Degree & 8 \\
\hline $12^{\text {th }}$ Grade Teacher 3 & Male & Master's Degree & 7 \\
\hline $12^{\text {th }}$ Grade Teacher 4 & Female & Master's Degree & 15 \\
\hline $\begin{array}{c}\text { Academic Intervention } \\
\text { Teacher } 1\end{array}$ & Female & Bachelor's Degree & 5 \\
\hline $\begin{array}{c}\text { Academic Intervention } \\
\text { Teacher } 1\end{array}$ & Female & Bachelor's Degree & 24 \\
\hline
\end{tabular}

English teacher break down.

The participants in this study exhibit a wide variety of teaching experience, with the most experienced teacher having taught for 37 years and least experienced teacher having taught for one year. Four of the teachers were male, and 14 were female. The teaching experience for these teachers averaged 13.4 years.

\subsection{Research Questions and Data Sources}

Within this mixed-methods study, different data sources were used in order to answer each research question.

1. What is the perception of WISD high school English teachers regarding the quality of the writing professional development they received through PLCs?

At the beginning of the study, all teachers were given a preliminary survey to identify the types of writing topics they wished to explore (i.e. Teaching grammar, teaching writing strategies, teaching parts of the writing process, understanding expectations for students in the writing standards, using mentor text to model good writing, conferencing with students, using rubrics for instruction and assessment, effective instruction for struggling writers, using the results of assessment to plan effective instruction, effective classroom management during writing instruction, teaching specific writing genres, integrating reading and writing into lessons, and 
other identified topics). Teachers rated their level of interest by indicating if it was a high, moderate or low-level priority.

The top six topics became focus areas for professional development during PLCs. The top six topics were: writing calibration, effective instruction for struggling writers, mentor text to model good writing (such as published pieces of literary or informational text), conferencing with students, teaching grammar through writing, and integrating reading and writing.

Two primary pieces of data were collected to gain insight into teachers' perceptions of the professional development offered at the end of the study. First, the researchers utilized an observation protocol for PLCs in order to observe behaviors and comments made during each professional development session provided each week for the English teachers. The observation involved both descriptive and reflective notes taken by the researchers (Creswell, 2013). There were a total of seven PLCs for each grade level where the observation protocol was used.

The second piece of data used to gain insight into teachers' perceptions of the professional development offered was a survey at the end of the study. The survey contained 10 questions that focused on the types of professional development offered, feelings about being involved as participants, use of strategies and information from the PD, adequacy of levels support, and perceptions of the writing team who delivered PD. All questions were based on a Likert-type scale with four options for response: Strongly Agree, Agree, Disagree, or Strongly Disagree (Appendix 1). Four of the questions also contained an open-ended response to further elaborate on that particular question.

The next three research questions were addressed simultaneously:

2. What differences occurred in writing instruction with four English teachers not on the writing team but who received professional development through Professional Learning Communities?

3. What differences occurred in writing instruction with the four teachers who are writing team members after conducting and receiving professional development through Professional Learning Communities?

4. What differences occurred in writing instruction with the three teachers who received instructional coaching in addition to writing professional development through Professional Learning Communities?

To answer these research questions data were collect from the $360^{\circ}$ Walkthrough Observation form used by all administrators in the district. This instrument was designed by the Region 20 Education Service Center in San Antonio, Texas, in 2007. All administrators have been extensively trained to use this instrument for all observations in the district, and this instrument has been used on a weekly basis for the last three school years. Observation data collected by using the $360^{\circ}$ Walkthrough instrument are based on five over-arching categories that pertain to what students are doing in classrooms: 
1. Learning process - learner engagement, success in learning, critical thinking and problem solving through level of cognition, self-direction, and connecting learning;

2. Learner-centered instruction-goals and objectives, learner-centered instruction, motivational strategies, curriculum alignment and pacing, appropriate questioning and inquiry, use of technology and tools;

3. Learner progress - monitoring and assessing, alignment of assessment and instruction, appropriate assessment for all students, reinforced learning, constructive feedback, and relearning or reevaluating;

4. Learner management-discipline procedures, self-direction, equitable student-teacher interactions, expectations for behaviors, redirection for disruptive behavior, reinforcement of desired behavior, equitable and various instructional materials, and management of time and materials; and

5. High-yield strategies/best practices such as cooperative groups, note taking, non-linguistic representations, graphic organizers, brainstorming, modeling, manipulatives, setting objectives, reinforcing efforts, and word walls.

For the purposes of this study, only specific areas within the district observation instrument were of focus because they aligned with the professional development topics provided during PLCs. Those focus areas analyzed were:

1. Learning process-learner engagement and critical thinking and problem solving through level of cognition (specifically, synthesis and evaluative levels).

2. Learner-centered instruction - motivational strategies used to teach writing.

3. Learner progress - monitoring and assessing students writing, appropriate assessment for all students (specifically, meeting the needs of struggling writers), and constructive feedback for students and their writing.

4. High-yield strategies/best practices such as use of graphic organizers, brainstorming, modeling, setting objectives, and reinforcing writing efforts of students.

Within the three groups, all teachers had received the professional development delivered weekly through their PLCs. The first group received weekly professional development, and participants in this group were teachers chosen to be a part of the district vertical writing team. The second group received only weekly professional development. The third group received weekly professional development just as the first two groups and worked with the on-site researcher who served as instructional coach for 10 weeks during the 15 -week time period of this study. Observation data were collected during unannounced walkthroughs and used to compare the three groups of teachers to determine the effects of the writing PD. The $360^{\circ}$ Walkthrough Observation form was used to create consistency across all observations. In addition to using the observation form for the teachers receiving coaching as a pre- and post-observation, the on-site researcher video recorded five observations. Teachers' evaluated and reflected on their lessons using these recorded observations for viewing. In between each 
recorded lesson, the on-site researcher met with each of these teachers individually to discuss and reflect on the taught lesson. The teachers were also to complete a Lesson Reflection Form (Hasbrouck \& Denton, 2005) prior to each meeting. The form asked teachers to reflect on their instructional goals, to discuss what happened in the lesson, what changes if any would they recommend, what should be retained in the lesson, and what the plan of the next lesson should be. Using the recording from the lesson reflection, and the observation notes, researchers, instructional coach, and the teacher would determine a plan for the next observed lesson. At the conclusion of the study, the on- site researcher conducted an individual interview with each participant (Appendix 2). Interviews and reflection forms were transcribed, analyzed and coded to determine themes or categories for the coaching experience.

The last research question was:

5. Did student achievement increase in writing in the $9^{\text {th }}$ grade teachers' classrooms on the STAAR Writing assessment from the pre-assessment to the post-assessment?

A total of 630 students took English I STAAR assessment as a pre-test prior to this study and the English I STAAR assessment in April as the post-assessment. The focus areas for analyses on both the pre-test and post-test were: overall revision of text, editing of text, revision of expository text, editing of sentence structure, editing of punctuation, and editing of spelling.

\section{Results}

Seven different sources of quantitative and qualitative data were analyzed to determine teachers' perceptions and implementations of professional development in writing instruction. Qualitative data were collected through an observation protocol used during PLCs to document teachers' behaviors and comments regarding professional development and teachers' perceptions of the quality, usefulness and importance of the training they received throughout the semester. Qualitative data were also collected using reflective forms completed after every coaching observation, and researcher interviews completed at the end of the coaching cycle. In addition, qualitative data were gathered at the end of the semester through administration of a survey of teachers' perceptions about the PD. Quantitative data were collected through preand post-observations (four writing team and, four non-writing team teachers), three teachers who received additional coaching, and students' pre- post-test writing growth measured by the STAAR writing assessment results of the $9^{\text {th }}$ grade team.

\subsection{Data Analysis for Research Question 1}

Reflection notes about WISD's quality of the writing PD were recorded during PLCs in order to determine teachers' behaviors and implementation of professional development being offered. In addition, a voluntary survey was given at the end of the study period, and all 18 English teachers were invited to partake of the survey in order to give their feedback and perceptions regarding the professional development that had been offered throughout the semester.

The reflection notes were analyzed using a constant comparative method (Creswell, 2013), whereby the data collected were used to determine "emerging categories" based on what the 
teachers said and the behavior they exhibited during their PLCs that involved professional development. During the 15-week study period, there were 28 PLC observations by the on-site researcher. Table 2 reflects the writing professional development topics that were shared throughout the weekly observation time period.

Table 2. Writing professional development topics

\begin{tabular}{|c|c|}
\hline PLC Week & Writing Topic \\
\hline Week 1 & Writing Calibration \\
\hline Week 2 & Writing Instruction for Struggling \\
& Writing Conferences \\
\hline Week 3 & Integrating Reading and Writing \\
\hline Week 4 & Using Mentor Text to Teach Writing \\
\hline Week 5 & Integrating Grammar and Writing \\
\hline Week 6 & Planning Future Writing Instruction \\
\hline Week 7 & \\
\hline
\end{tabular}

Weekly PD writing topics.

All 28 observation protocols were analyzed for evidence of language or behaviors that could be coded into broader categories in order to determine themes that emerged from the protocols. Three primary categories emerged as focus areas, or themes: collaboration, attitude of learning, and a willingness to try something new based on what was being learned. Through descriptive and reflective notes taken during each PLC, these themes emerged as teachers both responded to professional development being given either through body language or through verbal responses both during and after the professional development was given. As the protocols were analyzed the themes began to emerge.

One of the primary themes to emerge with the observation protocol used during the 28 PLC observations was the idea of collaboration. Both words and behaviors became evident with respect to collaboration. Some examples of both verbal cues and body language include the number of teachers participating, all teams participating, sharing ideas, verbal agreement, active conversations, enthusiasm in sharing, and rich discussions, etc.

The second theme that emerged was attitude of learning. Table 3provides a visual representation of the verbal and body language that were identified for this theme. 


\section{Macrothink}

Table 3. Theme of attitude of learning

\begin{tabular}{|c|c|c|c|}
\hline \multicolumn{2}{|c|}{ Body Language } & \multicolumn{2}{|c|}{ Verbal Language } \\
\hline Positive & Negative & Positive & Negative \\
\hline $\begin{array}{l}\text { Every team member was } \\
\text { very positive. }\end{array}$ & $\begin{array}{l}\text { One teacher did not } \\
\text { bring any writing } \\
\text { samples with her, even } \\
\text { though all were asked } \\
\text { to bring them. }\end{array}$ & $\begin{array}{c}\text { Teachers asked great } \\
\text { questions. }\end{array}$ & $\begin{array}{l}\text { One teacher repeatedly } \\
\text { does not offer any } \\
\text { information, questions or } \\
\text { advice. }\end{array}$ \\
\hline $\begin{array}{l}\text { Both teachers took notes } \\
\text { during the presentation. }\end{array}$ & $\begin{array}{l}\text { Unspoken tension } \\
\text { among the group }\end{array}$ & $\begin{array}{l}\text { Several commented } \\
\text { liking the checklist. }\end{array}$ & $\begin{array}{c}\text { One teacher responded } \\
\text { fairly negatively. }\end{array}$ \\
\hline $\begin{array}{l}\text { All teachers were very } \\
\text { attentive. }\end{array}$ & $\begin{array}{l}\text { Two teachers seemed } \\
\text { to be less engaged than } \\
\text { others based on eye } \\
\text { contact with the } \\
\text { presenter. }\end{array}$ & $\begin{array}{l}\text { This group is very good } \\
\text { about asking questions. }\end{array}$ & $\begin{array}{l}\text { Many comments were } \\
\text { negative. }\end{array}$ \\
\hline $\begin{array}{c}\text { All teachers were } \\
\text { attentive. }\end{array}$ & $\begin{array}{l}\text { This group's demeanor } \\
\text { tends to send messages } \\
\text { that they don't feel } \\
\text { these PLCs are } \\
\text { important. }\end{array}$ & $\begin{array}{l}\text { Everyone in the group } \\
\text { shared at least one idea. }\end{array}$ & $\begin{array}{c}\text { They all groaned saying } \\
\text { they had already done } \\
\text { these. }\end{array}$ \\
\hline $\begin{array}{l}\text { She nodded in } \\
\text { agreement through the } \\
\text { conversation. }\end{array}$ & $\begin{array}{l}\text { Eye rolling and body } \\
\text { posture/language }\end{array}$ & $\begin{array}{l}\text { They shared great ideas } \\
\text { for next year. }\end{array}$ & $\begin{array}{l}\text { One teacher complained } \\
\text { that there isn't anything } \\
\text { artistic for students to do } \\
\text { on the list given. }\end{array}$ \\
\hline
\end{tabular}

This group was very

attentive.

Both teachers were

attentive and

participatory.

Group's demeanor was

very positive and

agreeable.

All teachers paid

attention.

Generally very positive

Always the most

positive

They were very positive

Table 3 is a visual representation of the verbal and body language that were identified.

Following this analysis, the survey that all teachers were invited to take was analyzed to determine the correlation between what was seen in PLCs and what was shared in the survey 


\section{Macrothink}

(Table 4). The survey and the observations were analyzed together by comparing the behaviors and comments recorded in PLCs with the outcomes of each of the survey questions. Out of the 18 teachers who participated in the weekly professional development through PLCs, 15 completed the survey. The survey contained 10 questions; each was based on a Likert scale (Appendix 1).

Table 4. Summary of teachers' responses to final survey

\begin{tabular}{ccccc}
\hline Question & Strongly Agree & Agree & Disagree & $\begin{array}{c}\text { Strongly } \\
\text { Disagree }\end{array}$ \\
\hline 1 & 5 & 10 & 0 & 0 \\
\hline 3 & 6 & 8 & 1 & 0 \\
\hline 4 & 5 & 10 & 0 & 0 \\
\hline 5 & 4 & 8 & 3 & 0 \\
\hline 6 & 0 & 4 & 9 & 0 \\
\hline 7 & 7 & 8 & 0 & 0 \\
\hline $8 *$ & 8 & 7 & 0 & 0 \\
\hline 9 & 5 & 9 & 0 & 0 \\
\hline 10 & 5 & 9 & 4 & 0 \\
\hline 5 & 6 & 5 & & 0 \\
\hline
\end{tabular}

*Teacher skipped question

Teacher survey answers comparing behaviors.

Out of the 15 teachers who participated in the survey, all of them indicated on five of the survey questions that they either strongly agreed or agreed with what was being asked. Those five questions where there was agreement were: question 1 that asked teachers if they liked having the opportunity to give input into the type of writing professional development, question 3 that asked teachers if they have incorporated at least one new strategy or idea learned through professional development, question 6 that asked teachers if they liked working with their teams in PLCs to share ideas for writing, question 7 that asked teachers if they felt like they had been provided opportunities to learn from colleagues, and question 8 that asked teachers if they felt that the professional development they had received was useful in helping to improve student achievement. 
The open-ended response for the second question where teachers were asked to state which topic helped the most indicated that seven teachers felt that mentor text was the most helpful and six stated that conferencing was most helpful. Two teachers skipped the open-ended response for question two. One teacher disagreed on this question that any of the topics offered during the semester helped in teaching writing; however, this teacher also stated in the open-ended response that the use of mentor text was the most helpful topic.

The fourth question focused completely on the four teachers who are on the district writing team and their planning and delivery of several of the modules. Either the writing team members or the on-site researcher delivered the professional development during the semester. The only PLC where the writing team members or the researcher did not deliver the professional development was with the module on writing instruction for struggling learners, which was delivered by an outside writing consultant. Out of the 15 teachers answering the fourth question, three did not agree that the vertical writing team did a good job with the creation and delivery of the professional development modules.

The fifth question had the most teacher disagreement; however, that question asked teachers whether or not they felt they needed more support in implementing one or more of the new ideas into their classrooms. Nine of them did not feel they needed support.The last question asked teachers whether or not they felt their team values learning in PLCs. Four teachers indicated that they disagreed with this statement. Because this survey was anonymous, there is no way to determine which teachers felt this way about their PLC groups.

\subsection{Data Analysis for Research Questions 2-4}

The second, third and fourth research questions work individually and together as data are analyzed to determine changes in different groups of teachers. The second, third and fourth questions were:

2. What differences occurred in writing instruction with four English teachers who are not on the writing team but who received professional development in PLCs?

3. What differences occurred in writing instruction with the four teachers who are writing team members after conducting and receiving professional development in PLCs?

4. What differences occurred in writing instruction with the three teachers who received instructional coaching in addition to writing professional development in PLCs?

To analyze these three questions, they were first examined as three separate teacher groups. An unannounced observation was done on each teacher at the beginning of the semester before professional development began in PLCs and at the end of the semester after all professional development had concluded. The focus areas from the observation instrument analyzed for this study were:

1. Learning process-learner engagement and critical thinking and problem solving through level of cognition (specifically, synthesis and evaluative levels);

2. Learner-centered instruction - motivational strategies used to teach writing; 
3. Learner progress - monitoring and assessing students writing, appropriate assessment for all students (specifically, meeting the needs of struggling writers), and constructive feedback for students and their writing, and

5. High-yield strategies/best practices such as use of graphic organizers, brainstorming, modeling, setting objectives, and reinforcing writing efforts of students.

The first group of four teachers only received the writing professional development during the seven PLCs. They received no other professional development, support, or were served in any other capacity. A paired samples t-test was utilized to evaluate pre- and post-observation data on the identified related variables. Analysis revealed no significant differences on identified variables for the four teachers only receiving professional development in PLCs.

The second group of teachers was the four teachers who serve on the district writing team. In addition to receiving and assisting with the professional development during PLCs each week, they also received an additional layer of professional development by meeting with a district writing team who researched, analyzed data, and created writing professional development based on the identified needs of students. A paired samples t-test was utilized to evaluate preand post-observation data on the identified related variables. Analysis revealed no significant differences on identified variables for the writing team teachers.

The last group of teachers to be observed was three teachers who received the professional development during PLCs each week and also participated in instructional coaching with the researcher during the duration of the study. A paired samples t-test was utilized to evaluate preand post-observation data on the identified related variables. Analysis revealed no significant differences on identified variables for the three teachers who received professional development in PLCs and received instructional coaching.

In addition to the quantitative data for the teachers who participated in instructional coaching, these teachers were also video recorded during each observation and were asked to complete a Lesson Reflection Form to reflect on their own teaching as they watched their video. They discussed their reflections with the on-site researcher. There were five coaching sessions and five coaching observations over a 10 -week period of time. In addition, each teacher was interviewed at the end of the 15 weeks. Prior to the interview with each teacher, they were given the interview questions (Appendix 2) where they were asked to respond to the questions in writing and to bring them to the interview. The face-to-face interviews with these three teachers were recorded, and the recordings were transcribed. Transcriptions of recordings were compared to the transcriptions of written responses from the teachers regarding the questions asked in order to determine comparable statements between what they wrote and what they stated in the interview. The exact same questions were asked in the interviews that were asked for the written response. Each teacher used the paper as a reference during the interview but expanded on their written statements as they spoke.

Using these transcriptions and comparisons, along with the reflection notes the teachers completed after each observation categories as evidence arose from what each teacher said that 


\section{Macrothink}

began to become similar (Creswell, 2013). Following the identification of categories, themes were established that arose collectively from the transcriptions.

The three teachers who received instructional coaching were asked three questions pertaining to their overall experience at the end of the study. The three questions were:

1. What do you feel you learned from this experience?

2. What would you have liked to have seen happen during this experience that did not happen?

3. Do you feel the coaching experience has helped you reach the goals you set for yourself?

Within their reflection notes after each observation, the teachers were also asked five questions:

1. What were my goals?

2. What happened in the lesson?

3. What should I change?

4. What should stay the same?

5. What's my plan for next time?

Within the transcriptions of all three interviews and the reviewing of teachers' reflection notes, two major themes arose from their perceptions of being coached. Self-awareness and collaboration throughout the coaching process became immediately evident with each teacher. Table 5provides a visual of the awareness theme and examples from interview notes. 
Table 5. Awareness theme from interviews

"I've still got a ways to go on all of those things, but I think I got better."

"If I know you or another administrator are coming in to watch me do something and I want to do it well, I am going to practice it before then too."

"I was very conscious of everything going on."

"Which normal teaching is that, being so aware of..."

"I was thinking forward, ahead of time."

"I listed my three I felt I grew the most in, and that was pushing low readers, challenging my GT kids, and the higher level thinking skills, and then conferencing."

"I learned some of my own behaviors, I guess, that I have in front of the room and in front of the kids that I don't pay attention to."

I learned more about "engagement of the kids more from watching the videos."

From the videos, "it's the little things you don't notice you're doing."

"The videos were the most integral part because I could watch them, I could make observations, I could reflect, and then I could think about it until the next time or even the next day."

"I feel like from where we started and the battles we had, we came a long way in those five weeks."

"I think it's just really beneficial because there are so many things about yourself you don't even realize unless you see it."

I also noticed that my two classes who struggle the most are my $6^{\text {th }}$ and $7^{\text {th }}$ periods, which are my last two classes."

"I believe the lesson was way too long and needs to be shortened."

"I felt like I left more time for students to ask questions at the end; though, I think I could have left even more time."

Examples of the collaboration theme emerging from interviews are found in Table 6. 
Table 6. Collaboration theme from interviews

\section{Examples from Interviews}

"if you say, "you really need to work on your questioning strategies-let me show you what that looks like next time."”

"If I get an intern... we would go and observe a class during the conference for like 20-30 minutes. We would come back and compare notes to discuss ..."

“it won't be like, I teach and you stay off to the side. We'll both be in front of that room together."

"It holds you accountable."

"I like having goals set at the beginning and working together towards those goals."

"if we had someone who was always here who was room to room constantly...you could just say, 'hey, I am struggling with this..."

"I almost don't want people to tell me when they are going to show up. Give me maybe a window of like sometime this month I'll be there...I want you to see the majority rather than me putting on a show."

\subsection{Data Analysis for Research Question 5}

In order to answer the fifth research question regarding whether or not student achievement increased significantly in the $9^{\text {th }}$ grade teachers' classrooms, a percent change on the STAAR Writing assessment was calculated from students' pre-test and post-test scores. An independent samples $t$ test was conducted to determine whether significant differences existed between teachers who received instructional coaching along with weekly professional development and teachers who only received weekly professional development. Evaluation of statistical data revealed no significant differences between the groups in any of the assessed STAAR variables. However, it is worth noting that there was a trend toward students' improving more on the mechanics of their writing, for example editing of punctuation and sentence structure and revision of narrative text.

\section{Discussion}

This mixed-methods study sought to examine the perceptions of teachers regarding professional development they received to become better writing teachers, and to examine the impact of that professional development as seen in classrooms.

The high school campus in WISD implemented PLCs two years ago. This campus was halfway through their second year of implementation when this study began. Their administrators had given teachers norms as to how PLCs should occur, and they had been given a focus area for 
each day of the week. Prior to this study, teachers were on their own to ensure that the focus areas were covered each day of the week. Researchers found prior to the study that little professional development was occurring with these teachers beyond the minimum of two days required of them annually by the school district that was outside of their teaching contract. The desire of the district administration was that writing proficiency for high school students improve, and the campus administration wanted PLCs to be more effective in order to help reach the goal of improving writing proficiency. Research efforts were made to create continuity with weekly professional development and to ask teachers what they desired to learn during the PLCs. Through utilizing the time through PLCs and the feedback from teachers on areas they wished to receive during professional development, PLCs were focused on those areas. Four of the teachers were also a part of a district writing team that met monthly with the researcher to investigate and problem solve the writing weaknesses at the secondary level. Instructional coaching was an added layer of support for three teachers who volunteered to work with the on-site researcher as an instructional coach in addition to participating in the weekly professional development that all other teachers received. The structure of the PD during PLC for this study followed the suggestions of Loucks-Horsley, et. al (2010) to ensure the transfer of learning gained from the PD to changes of pedagogy in the classroom.

This study revealed that teachers were not used to having a detailed focus for professional development during their PLC, nor were they used to having an administrator present each week for a PLC in order to ensure that ongoing professional development occurred. The qualitative results revealed that teachers perceived the professional development offered to be a positive experience and agreed that they not only valued having input on the topics covered, but they tried to implement one or more of the learned strategies. Most teachers also felt that the professional development they received during this time period was valuable to them. The themes that presented themselves from the observed PLCs (collaboration, attitude of learning, and willingness to try something new) displayed more positive outcomes than negative with all 18 English teachers as they worked to establish an ongoing professional development approach. However, the survey also revealed that several teachers do not feel that all colleagues value the learning that takes place during PLCs. That data parallels some of the negative verbal and body language recorded during PLCs. Similar mixed results have been found when the focus is science content instead of writing (Jones, Gardner, Robertson, \& Robert, 2013).

The instructional coaching layer included observations, reflection forms, and interviews with the researcher. Although pre- and post-observations did not reveal significant changes with these three teachers, the qualitative data, similar to Phillips, et al. (2016) did reveal that these teachers became much more aware of themselves as teachers and more reflective in regard to what should and should not be occurring in their instructional lessons. They had the opportunity to view themselves teach through recorded videos, and they were able to collaborate and dialogue after every recorded lesson, which provided them the opportunity to reflect and analyze their own teaching practices. These occurrences received very positive feedback from all three teachers who participated, and they not only wanted to continue with instructional coaching, but they also wished more teachers would be willing to participate. The current study supported a recent longitudinal study that demonstrated that the combination of 
instructional coaching and sustained PD increases teachers use and continued use of different pedagogical strategies (Teemant, 2014).

The quantitative data determined that some significant changes occurred with teachers from the pre- and post-observations, which were seeking implementation of strategies and discussions learned during the PLCs. These observations were two data points that occurred one time at the beginning and one time at the end of the study. Although observations were done with hopes of seeing implementation of one or more of the learned strategies through professional development, they did not reveal that implementation of these learned strategies were occurring in all of the classrooms at the time of the post observation. However, even though the quantitative data did not indicate that implementation of learned strategies had occurred, the qualitative data did indicate that there is a progression of change in thinking and collaborating in professional development with the high school English teachers at WISD.

The practical implications of this study suggest that this campus must continue to create structure and delineate accountability with PLCs so that teachers see the daily time given as an opportunity to be learners who have time to collaborate and learn from one another. Research shows that PLC can increase teachers' knowledge, change instructional practice and increase student achievement (Vescio, Ross, \& Adams, 2007). The idea of connecting all PLCs each week will enforce and strengthen this learning and reflection time for teachers. Campus leaders can continue to expect and to encourage teachers to determine their needs and to seek ways to meet those needs during PLCs. Campus leaders can also consider more ways of incorporating instructional coaching where needed or desired by teachers. As Limbrick, et al. (2010) conclude, when teachers see themselves teaching, are provided with opportunities to work with someone they trust and respect, and provided with time to reflect on their practices, their desire to become stronger teachers will naturally occur.

\section{Limitations}

This study took place on one high school campus and examined 18 English teachers during a 15-week period of time during PLCs and instructional coaching. The results of this study suggest that PLCs can be powerful for teachers in order to collaborate and to learn new strategies to improve their own instruction. The results also suggest that instructional coaching, when the relationship between the coach and the teacher is strong, trustworthy and respectful, can aid in teachers becoming more aware of their own teaching practices and create a desire for more collaboration in order to become stronger teachers. However, there are three recommendations for future research as to how this study could have been enhanced or improved. The three recommendations that could have improved this study are: exploring how other PLC focus areas connect to the professional development focus, exploring more student assessment data in relation to PLC practices, and extending the amount of time for the study.

In this study, only one PLC focus area was studied: professional development. The teachers also have focus areas of data, technology and lesson planning in their PLCs the other days of each week. By including the focus areas of data, technology and lesson planning as they connect to professional development, conclusions could be made as to how they affect student achievement in writing. 
Additionally, including more student assessment data in a study could provide evidence as to whether or not PLCs are making a difference in students' mastery of writing proficiency. This study only included the STAAR writing data of the ninth grade and only included certain skills that were assessed. No essay scoring data was included due to the extenuating details included in the scoring process. However, other research could examine individual student essays to determine if instructional strategies used to teach specific writing skills have an impact on essay writing.

Extending the amount of time of this study could also offer more information. This study took place over a 15-week time period. During that time period, there were seven PLCs per grade level devoted to different writing professional development focus areas. Along with the professional development provided during PLCs, there were also 10 weeks of instructional coaching that took place with three teachers. Because PLCs are still new to this campus, the attitude and desire of teachers to use that time to improve professionally still lacks in a few of the teachers. Along with trying to create norms and a regular occurrence of professional development each week for the teachers, some teachers still did not want to buy in to the reasons for why this ongoing professional development was important. With a longer period of time and set expectations for learning, research could be conducted to better determine the effects of having PLCs devoted to professional development and how that impacts student performance.

By collecting data on how all PLC focus areas work together, extending the amount of student data, and extending the length of time for the study, the connection could possibly better be made between teacher learning and student performance improvement.

\section{References}

Anderson, R., Feldman, S., \& Minstrell, J. (2014). Understanding relationship: Maximizing the effects of science coaching. Education Policy Analysis Archives, 22(54), 1-25. http://dx.doi.org/10.14507/epaa.v22n54.2014

Applebee, A.N., \& Langer, J.A. (2009). What is happening in the teaching of writing? The English Journal, 98(5), 18-28.

Archibald, S., Coggshall, J.G., Croft, A., \& Goe, L. (2011). High quality professional development for all teachers: Effectively allocating resources. Washington, DC: National Comprehensive Center for Teacher Quality.

Blankstein, A. M. (2004). Failure is not an option: Six principles that guide student achievement in high-performing schools. Thousand Oaks: CA, Corwin Press.

Chung Wei, R., Darling-Hammond, L., \& Adamson, F. (2010). Professional development in the United States: Trends and challenges. Executive Summary (Phase II Report). Retrieved http://www.learningforward.org/docs/pdf/nsdcstudy2010.pdf?sfvrsn=0

Collazo, S., \& Gonzales, S. (2007). 360 Walkthrough Observation. Region 20 Education Service Center San Antonio, Texas. 
Creswell, J. W., Plano Clark, V. L., Gutmann, M., \& Hanson, W. (2003). Advanced mixed methods research designs. In A. Tashakkori\& C. Teddlie (Eds.), Handbook of mixed methods in social and behavioral research (pp. 209-240). Thousand Oaks, CA: Sage Publications.

Creswell, J. W. (2013). Qualitative inquiry \& research design: Choosing among five approaches. Los Angeles, CA: Sage Publications.

Creswell, J. W. (2014). Research design: Qualitative, quantitative, and mixed methods approaches $\left(4^{\text {th }}\right.$ ed. $)$. Los Angeles, CA: Sage Publications.

Darling-Hammond, L. (1995). Changing conceptions of teaching and teacher development. Teacher Education Quarterly, 22(4), 9-26).

Darling-Hammond, L., Chung Wei, R., Andree, A., Richardson, N., \& Orphanos, S. (2009a). Professional learning in the learning profession: A status report on teacher development in the United States and abroad. Executive Summary (Phase I Report). Retrieved from http://www.learningforward.org/docs/pdf/nsdestudy2009.pdf?sfvrsn=0

Darling-Hammond, L., Chung Wei, R., Andree, A., Richardson, N., \& Orphanos, S. (2009b). Forward. Professional learning in the learning profession: A status report on teacher development in the United States and abroad. Executive Summary (Phase I Report) (p. 3). Retrieved from Learning Forward website http://www.learningforward.org/docs/pdf/nsdcstudy2009.pdf?sfvrsn=0

Desimone, L. M. (2009). Improving impact studies of teachers' professional development: Toward better conceptualizations and measures. Educational Researcher, 38(3), 181-199. http://dx.doi.org/10.3102/0013189X08331140

DuFour, R., \& Eaker, R. (1998). Professional learning communities at work: Best practices for enhancing student achievement. Bloomington, IN: Solution Tree.

DuFour, R. (2004). What is a professional learning community? Educational Leadership, 61(8), 6-11.

DuFour, R., Dufour, R., \& Eaker, R. (2008). Revisiting professional learning communities at work: New insights for improving schools. Bloomington, IN: Solution Tree.

Fearn, L., \& Farnan, N. (2007). The influence of professional development on young writers' writing performance. Action in Teacher Education, 29(2), 17-28. http://dx.doi.org/10.1080/01626620.2007.10463445

Fleischer, C. (2004). Professional development for teacher-writers. Educational Leadership, 62(2), 24-28.

Flint, A.S., Zisook, K., \& Fisher, T.R. (2011). Not a one-shot deal: Generative professional development among experienced teachers. Teaching and Teacher Education, 27, 1163-1169. http://dx.doi.org/10.1016/j.tate.2011.05.009

Goodwin, B. (2014). Teach critical thinking to teach writing. Alexandria: Association for Supervision and Curriculum Development. 


\section{Macrothink}

Journal of Studies in Education

ISSN 2162-6952

2016, Vol. 6, No. 3

Guskey, T. (2009). Closing the knowledge gap on effective professional development. Educational Horizons, 87(4), 224-233.

Graham, S., \& Perin, D. (2007). Writing next: Effective strategies to improve writing of adolescents in middle and high schools - a report to Carnegie Corporation of New York. Washington, DC: Alliance for Excellent Education.

Hasbrouck, J., \& Denton, C. (2005). The reading coach: A how-to manual for success. Longmont, CO: Sopris West.

Heilman, A.J., Blair, T.R., \& Rupley, W. H. (2002). Principles and practices of teaching reading.Principals and Practices of Teaching Reading. (10th ed.). Columbus, OH: Merrill.

Jaquith, A. (2013). Instructional capacity: How to build it right. Educational Leadership, 71(2), 56-61.

Jones, M. G., Gardner, G. E., Robertson, L., \& Robert, S. (2013). Science professional learning communities: Beyond a singular view of teacher professional development.International Journal of Science Education, 35(10), 1756. http://dx.doi.org/10.1080/09500693.2013.791957

Joyce, B., \& Showers, B. (2002). Student achievement through staff development $\left(3^{\text {rd }}\right.$ ed.). Alexandria, VA: ASCD.

Knight, J. (2009a). Coaching: The key to translating research into practice lies in continuous, job-embedded learning with ongoing support. National Staff Development Council, 30(1), $18-22$.

Knight, J. (2009b). The big four: A simple \& powerful framework to dramatically improve instruction. Strategram, 21(4), 1-7.

Lewis, L.K. (2011). Organizational change: Creating change through strategic communication. Malden, MA: Wiley-Blackwell.http://dx.doi.org/10.1002/9781444340372

Limbrick, L., Buchanan, P., Goodwin, M., \& Schwarcz, H. (2010). Doing things differently: The outcomes of teachers researching their own practice in teaching writing. Canadian Journal of Education, 33(4), 897-924.

Lotter, C., Yow, J.A., \& Peters, T.T. (2014). Building a community of practice around inquiry instruction through a professional development program. International Journal of Science and Mathematics Education, 12, 1-23.http://dx.doi.org/10.1007/s10763-012-9391-7

Loucks-Horsley, S., Stiles, K.E., Mundry, S., Love, N., \& Hewson, P.W. (2010). Designing professional development for teachers of science and mathematics $\left(3^{\text {rd }} \mathrm{ed}\right.$.). Thousand Oaks, CA: Corwin Press, Inc.

Marzano, R.J., Waters, T., \& McNulty, B.A. (2005). School leadership that works: From research to results. Alexandria, VA: ASCD. 
Mehta, S. R., \& Al-Mahrooqi, R. (2015). Can thinking be taught? Linking critical thinking and writing in an EFL context. RELC Journal, 46(1), 23-36.http://dx.doi.org/10.1177/0033688214555356

NAEP. (2012). The condition of education, 2012: elementary and secondary education. Retrieved from http://nces.ed.gov/programs/coe/introduction2.asp

National Council of Teachers of English. (2015). NCTE guideline: NCTE beliefs about the teaching of writing. Retrieved from http://www.ncte.org/positions/statements/writingbeliefs

OECD (2014) New Insights from TALIS 2013 Teaching and Learning in Primary and Upper Secondary Education.

Phillips, D., Nichols, W.D, Rupley, W., Page, D., \& Rasinski, T. (2016). Efficacy of professional development: Extended use of focused coaching on guided reading instruction for teachers of grades one, two, and three. International Research in Higher Education, 1(2) 12-24. http://dx.doi.org/10.5430/irhe.v1n2p12

Prytula, M.P. (2012). Teacher metacognition within the professional learning community. International Education Studies, 5(4), 112-121.http://dx.doi.org/10.5539/ies.v5n4p112

Reither, J.A. (1985). Writing and knowing: Toward redefining the writing process. College English, 47(6), 620-628.http://dx.doi.org/10.2307/377164

Rupley, W. H., Nichols, W. D., \& Blair, T. R. (2008). Language and culture in literacy instruction: Where have they gone? The Teacher Educator, 43(3), 238-248.http://dx.doi.org/10.1080/08878730802055180

Schmoker, M. (2006). Results now: How we can achieve unprecedented improvements in teaching and learning. Alexandria, VA: ASCD.

Teemant, A. (2013). A mixed method investigation of instructional coaching for teachers of diverse learners. Urban $\quad$ Education, 574-604.http://dx.doi.org/10.1177/0042085913481362

Teemant, A. (2014). A mixed-methods investigation of instructional coaching for teachers of diverse learners. Urban Education, 49(5), 574-604. http://dx.doi.org/10.1177/0042085913481362

Texas Education Agency. (2011). Frequently asked questions: General questions. Retrieved from http://www.txetests.com/FAQS/FAQ.asp?ID=1\&p=2\&c=3

Texas Education Agency. (2012). Academic excellence indicator system: 2011-2012 district performance.

Retrieved

from

http://ritter.tea.state.tx.us/cgi/sas/broker?_service=marykay\&_program=perfrept.perfmast.sas \&prgopt $=2012 \% 2$ Faeis $\% 2$ Falltyped.sas $\&$ year $4=2012$ \&year $2=12 \&$ topic $=$ aeis $\&$ gifname $=\% 26$ GIFNAME\&title=AEIS\%2BReport\&level=district\&search=distback\&sublevel=dist\&ptype= HTML\&distback=161903+ 
Texas Education Agency. (2013). 2012-2013 Texas academic performance report. Retrieved from http://ritter.tea.state.tx.us/perfreport/tapr/2013/srch.html?srch=D

Texas Education Agency. (2014a). 2013-2014 Texas academic performance report. Retrieved from http://ritter.tea.state.tx.us/perfreport/tapr/2014/srch.html?srch=D

Texas Education Agency. (2014b). Chapter 1: Historical overview of assessment in Texas. Technical Digest 2013-2014. Retrieved from http://tea.texas.gov/Student_Testing_and_Accountability/Testing/Student_Assessment_Over view/Technical_Digest_2013-2014/

Texas Education Agency. (2014c). Chapter 2: State of Texas assessments of academic readiness (STAAR). Retrieved from http://tea.texas.gov/Student_Testing_and_Accountability/Testing/Student_Assessment_Over view/Technical_Digest_2013-2014/

Texas Education Agency. (2014d). Texas Academic Performance Report. Retrieved from http://ritter.tea.state.tx.us/cgi/sas/broker?_service=marykay\&year4=2014\&year2=14\&_debug $=0 \&$ single $=\mathrm{N} \&$ title $=2014+$ Texas + Academic + Performance + Reports $\& \_$program $=$perfrept.perf mast.sas\&prgopt $=2014 \% 2 \mathrm{Ftapr} \% 2 \mathrm{Ftapr}$.sas \&ptype=P\&level=campus\&search $=$ campname $\&$ namenum $=$ Midway $+\&$ campus $=161903001$

Texas Education Agency. (2015a). STAAR resources: A comparison of assessment attributes TAKS to STAAR. Retrieved from http://tea.texas.gov/student.assessment/staar/

Texas Education Agency. (2015b). English Language Arts and Reading. Retrieved from http://tea.texas.gov/Curriculum_and_Instructional_Programs/Subject_Areas/English_Langua ge_Arts_and_Reading/English_Language_Arts_and_Reading/

Texas Education Agency. (2015c). STAAR resources: TEA update on the STAAR program. Retrieved from http://tea.texas.gov/student.assessment/staar/

Texas Education Agency. (2015d). 2012-2013 school report card. Retrieved from http://ritter.tea.state.tx.us/perfreport/src/2013/campus.srch.html

Troia, G., Lin, S., Cohen, S., \& Monroe, B. (2011). A year in the writing workshop. The Elementary School Journal, 112(1), 155-182.http://dx.doi.org/10.1086/660688

Vescio, V., Ross, D., \& Adams, A. (2008).A review of research on the impact of professional learning communities on teaching practice and student learning.Teaching and Teacher Education, 24(1), 80-91. http://dx.doi.org/10.1016/j.tate.2007.01.004

Yoon, K., Duncan, T., Lee, S., Scarloss, B., \& Shapley, K. (2007). Reviewing the evidence on how teacher professional development affects student achievement. Washington, DC: US Department of Education, Regional Educational Laboratory Southwest. Retrieved from http://ies.ed.gov/ncee/edlabs/regions/southwest/pdf/rel_2007033.pdf

Zaner-Bloser. (2015). What is writer's workshop? Retrieved from https://www.zaner-bloser.com/news/writers-workshop. 


\section{Appendix 1. Professional Development—English Teacher Survey: Spring 2015}

Throughout this spring semester, you have participated in writing professional development during your Friday PLCs. Please indicate your level of agreement to the following statements.

Strongly Agree

Agree

Disagree

Strongly Disagree

1. I liked having the opportunity to give input about what writing topics were addressed in our professional development PLCs this spring.

Strongly Agree Agree Disagree Strongly Disagree

2. I feel that at least one of the topics covered during this semester helped me in teaching writing.

Strongly Agree Agree Disagree Strongly Disagree

- The most helpful topic for me was

3. I have incorporated one or more of the strategies or ideas shared in our PLCs this spring.

Strongly Agree Agree Disagree Strongly Disagree

- The idea(s) and/or strategy(ies) I have incorporated are

4. Our vertical writing team did a good job of creating modules to address chosen writing topics.

Strongly Agree Agree Disagree Strongly Disagree

- The most effective module(s) for me was/were

5. I feel like I need more support in implementing one or more of the writing ideas into my classroom.

Strongly Agree Agree Disagree $\quad$ Strongly Disagree

- I needed more support in implementing this/these idea(s).

6. I like working with my team in PLCs to share information on implementing writing ideas and strategies.

Strongly Agree Agree Disagree Strongly Disagree

7. I feel like I have been provided opportunities to learn from my colleagues.

Strongly Agree Agree Disagree $\quad$ Strongly Disagree

- One specific piece of new learning I acquired this semester was 
8. I feel like professional development this semester in the area of writing has been useful to $\mathrm{ME}$ in my efforts to improve student achievement.

Strongly Agree Agree Disagree Strongly Disagree

9. I feel like I have contributed to the learning environment within my PLC this semester.

Strongly Agree Agree Disagree Strongly Disagree One way I have contributed to my PLC is

10. I feel like my team values the learning that takes place in PLCs.

Strongly Agree Agree Disagree $\quad$ Strongly Disagree

\section{Appendix 2. Coaching Semi-structured Interview}

- This semester, you participated in a coaching experience with me in order to address goals you had for your own teaching. Talk about this experience and what you felt went well and what didn't.

o What do you feel you learned from this experience?

o What would you have liked to have seen happen during this experience that did not happen?

o Do you feel the coaching experience has helped you to reach the goals you set for yourself at the beginning of the semester? 